\title{
Enzyme Histochemical Studies on Bovine Leukemia Cells
}

Takashi YOSHIKAWA, Takaaki YAMAMURA, Hiroyasu YOSHIKAWA, and Toshifumi OYAMADA

Department of Veterinary Pathology, School of Veterinary Medicine and Animal Sciences, Kitasato University, Towada, Aomori 034, Japan

(Received 2 February 1984/Accepted 28 April 1984)

\begin{abstract}
Enzyme histochemical activities of adenosin triphosphatase (ATPase) and acid phosphatase (AcPase) were studied on the superficial cervical lymph nodes in 18 cattle of bovine leukosis (12 adult form, 3 calf form, 3 thymic form). Similar tissues from 5 healthy cattle served as controls. ATPase gave a brown positive reaction corresponding to the lymphocyte membrane in the B lymphocyte dependent area. In cytoplasms of lymphocyte in the paracortex of $\mathrm{T}$ lymphocyte dependent area, accumulation of dark-brown granules indicating AcPase activity was noted. In 10 leukemic cattle of adult form, the neoplastic cells definitely revealed ATPase activity. Neoplastic cells of 6 cattle of thymic and calf form rarely revealed ATPase activity, and all exhibited specific reactions by the accumulation of AcPase positive granules. Accumulation of AcPase positive granules was demonstrated as clustered dense body electron microscopically.-Key words: bovine leukosis, cytoenzymology, ATPase, AcPase, ultrastructure.
\end{abstract}

Jpn. J. Vet. Sci. 46(4): 541-547, 1984

\section{INTRODUCTION}

Due to the recent developement of immunology, differentiation of lymphocytes into $\mathrm{T}$ and $\mathrm{B}$ cells was demonstrated, along with the immunological role of each. Bovine leukosis, a tumor of lymphocytic origin, has also been studied from the functional and morphological concepts. Neoplastic cells of adult form leukosis have the properties of $B$ lymphocytes $[2,12,16]$ and of thymic and calf forms are known to have properties of $\mathrm{T}$ lymphocytes [23]. Recently, the enzyme histochemical characteristics of human lymphocytes have received attention. The adenosine triphosphatase (ATPase) present on the cell membrane represents a marker enzyme for $B$ lymphocytes $[6,11,14]$, while acid phosphatase (AcPase), a lysosomal enzyme, is a marker enzyme for $\mathrm{T}$ lymphocytes $[5,15,20$, 22].

Investigation of the activity of these two enzymes represents a useful method for the understanding of bovine leukemia cells. From this viewpoint, the enzyme activity of several patterns of bovine leukemia cells was studied with reference to their ultrastructure.

\section{MATERIALS AND METHODS}

Tissue samples: Tumor tissue specimens from 18 leukemic cattle (determined at necropsy, 12 adult form, 3 calf form, 3 thymic form) and 5 healthy cattle were studied (Table 1). All the cattle with adult from leukosis were seropositive for antibody to bovine leukemia virus (BLV), by the immunodiffusion (ID) test using glycoprotein antigen of BLV as descreibed previously [10].

Enzyme histochemisty: Superfical lymph nodes removed at autopsy were divided into small pieces of $5 \times 5 \times 1 \mathrm{~mm}$, and immediately frozen with liquid nitrogen. The frozen material was sectioned by cryostat, followed by fixation in $10 \%$ formol-calcium solution $(\mathrm{pH}$ 7.2). Demonstration of ATPase and AcPase activities was carried out by Wachstein- 
Table 1. Investigated cases of leukemic cattle

\begin{tabular}{|c|c|c|c|c|c|}
\hline \multicolumn{4}{|c|}{ Cattle } & \multirow{2}{*}{$\begin{array}{l}\text { Clinical } \\
\text { form }\end{array}$} & \multirow{2}{*}{$\begin{array}{l}\text { Immunodiffusion } \\
\text { test }^{c)}\end{array}$} \\
\hline No. & Breed $^{\text {a) }}$ & $\begin{array}{c}\text { Age } \\
\text { (in years) }\end{array}$ & Sex ${ }^{b)}$ & & \\
\hline 1 & $\mathrm{HF}$ & 5 & $\mathrm{~F}$ & Adult & + \\
\hline 2 & JS & 6 & $\mathrm{~F}$ & Adult & + \\
\hline 3 & JS & 6 & $\mathrm{~F}$ & Adult & + \\
\hline 4 & JS & 6 & $\mathrm{~F}$ & Adult & + \\
\hline 5 & JS & 7 & $\mathrm{~F}$ & Adult & + \\
\hline 6 & $\mathrm{HF}$ & 8 & $F$ & Adult & + \\
\hline 7 & $\mathrm{HF}$ & 10 & $\mathrm{~F}$ & Adult & + \\
\hline 8 & JS & 11 & $\mathrm{~F}$ & Adult & + \\
\hline 9 & JS & 11 & $\mathrm{~F}$ & Adult & + \\
\hline 10 & JS & 12 & $F$ & Adult & + \\
\hline 11 & $\mathrm{HF}$ & 12 & $\mathrm{~F}$ & Adult & + \\
\hline 12 & JS & 13 & $\mathrm{~F}$ & Adult & + \\
\hline 13 & $\mathrm{HF}$ & 1.5 & $F$ & Calf & - \\
\hline 14 & $\mathrm{HF}$ & 1.5 & $\mathrm{~F}$ & Calf & - \\
\hline 15 & $\mathrm{HF}$ & 0.5 & $\mathbf{M}$ & Calf & - \\
\hline 16 & HF & 2 & $\mathbf{M}$ & Thymic & - \\
\hline 17 & JS & 2 & $\mathbf{M}$ & Thymic & - \\
\hline 18 & HF & 0.5 & $\mathbf{M}$ & Thymic & - \\
\hline
\end{tabular}

a) $\mathrm{HF}=$ Holstein Friesian; JS = Japanese Shorthorn

b) $\mathrm{F}=$ female; $\mathrm{M}=$ male

c) $+=$ positive; $-=$ negative

Meisel [18] and Barka-Anderson methods [3]. In AcPase reaction, for the examination of the specificity of the substrate, reaction with a solution after removal of the substrate and inhibition test with tartrate were also conducted.

Electron microscopy: In 6 cattle ( 3 adult form, 2 thymic form and one calf form), the enlarged superficial cervical lymph nodes were studied. The small tissue fragments obtained were prefixed in paraformaldehydeglutaraldehyde mixture, followed by postfixation with $1 \%$ osmic acid. The specimens were then embedded in Epon in the standard manner. Following a double stain with uranyl acetate and lead citrate the ultrathin sections were examined with the Hitachi HS-8 Type electron microscope.

\section{RESULTS}

Enzyme activity in the normal lymph nodes: In the superficial cervical lymph nodes of healthy cattle, lymphocytes in the B lym- phocyte dependent area such as cortical primary follicles, mantle of germinal centers and medullary cords showed ATPase activity. In the germinal centers of secondary follicles, on the other hand, only a small number of cells demonstrated a positive reaction and many of the paracortical lymphocytes revealed a negative reaction. Positive cells exhibited brown ring-like staining corresponding to the cell membrane. AcPase activity was noted in the paracortical lymphocytes, sinus endothelial cells and macrophages. The sites of AcPase activity in these cells appeared as dark brown granules, scattered within the cytoplasm. Most of these reactions were inhibited by tartrate. Pattern of AcPase activity may be classified into three types. In type I, several fine granules were scattered within the cytoplasm. In type II, fine to large granules were accumulated on one side of the cytoplasm. In type III, large granules were irregularly distributed within the cytoplasm. Cells exhibiting type II reaction (type II cells) 


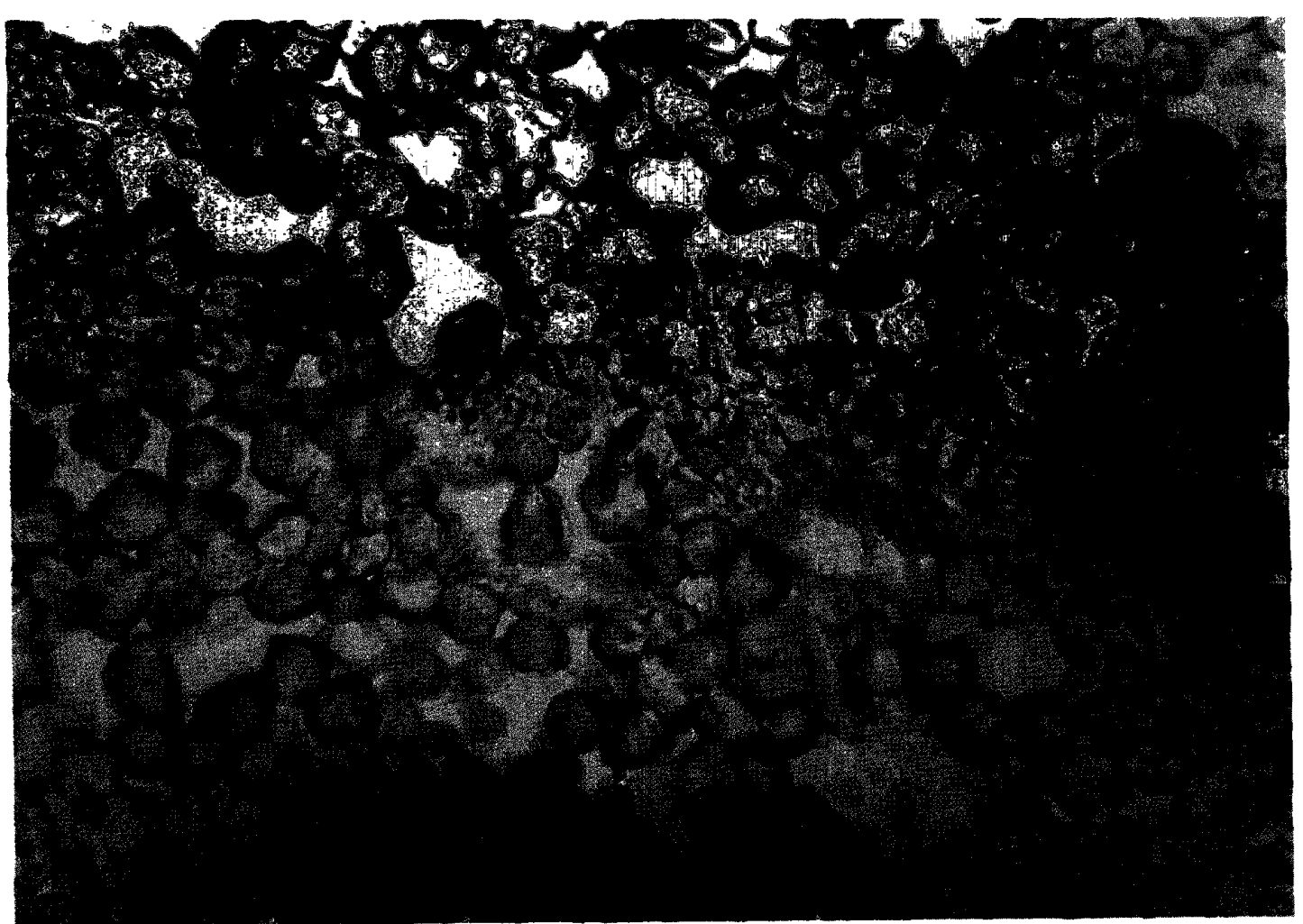

Fig. 1. Case No. 6; adult form. Neoplastic cells in cervical lymph node. ATPase positive cells exhibit brown ring-like staining corresponding to the cell membrane. $\times 726$.

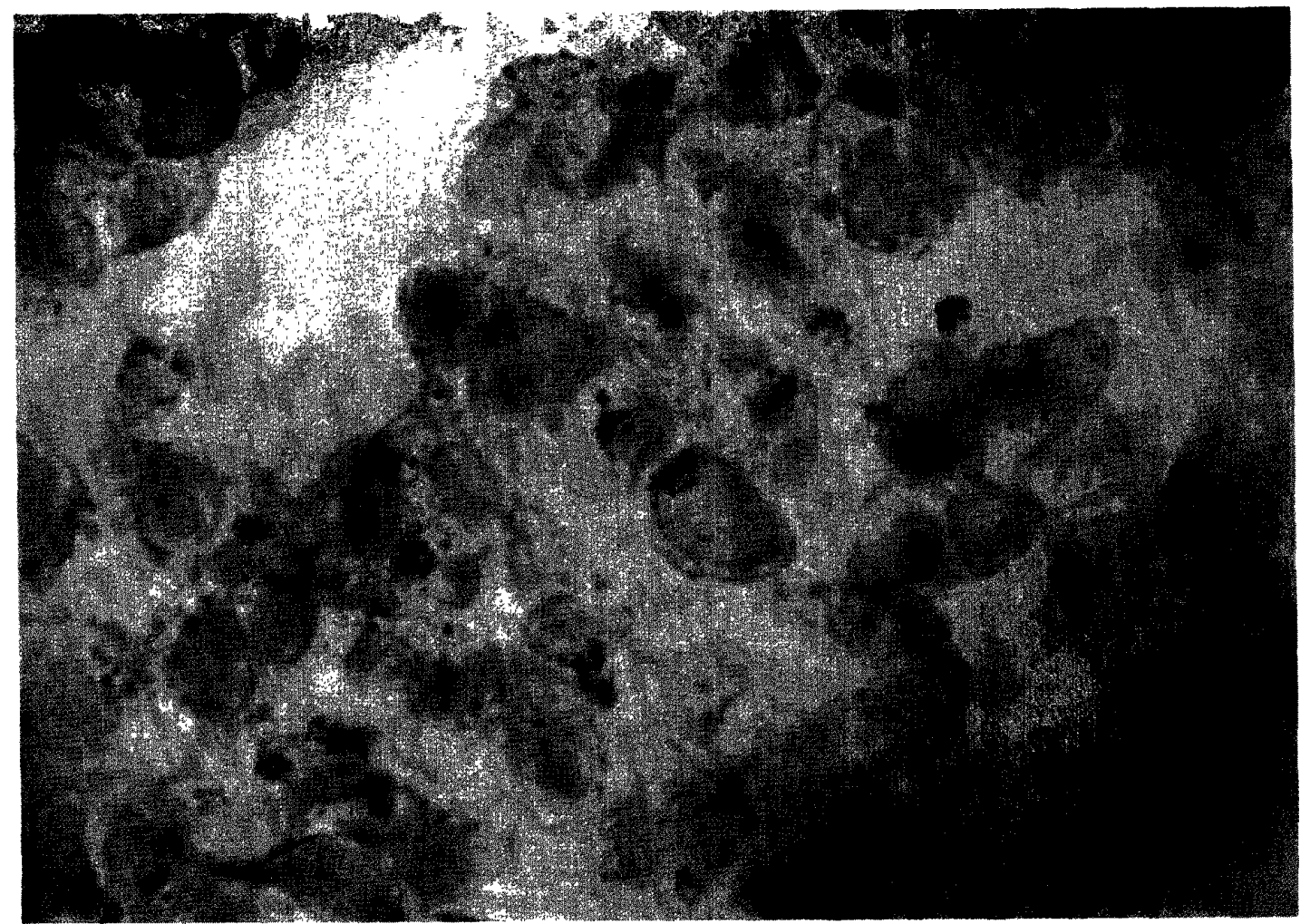

Fig. 2. Case No. 16; thymic form. Acid phosphatase reaction of neoplastic cells in cervical lymph node, showing positive particles in narrow rim of cytoplasm. $\times 1,320$. 


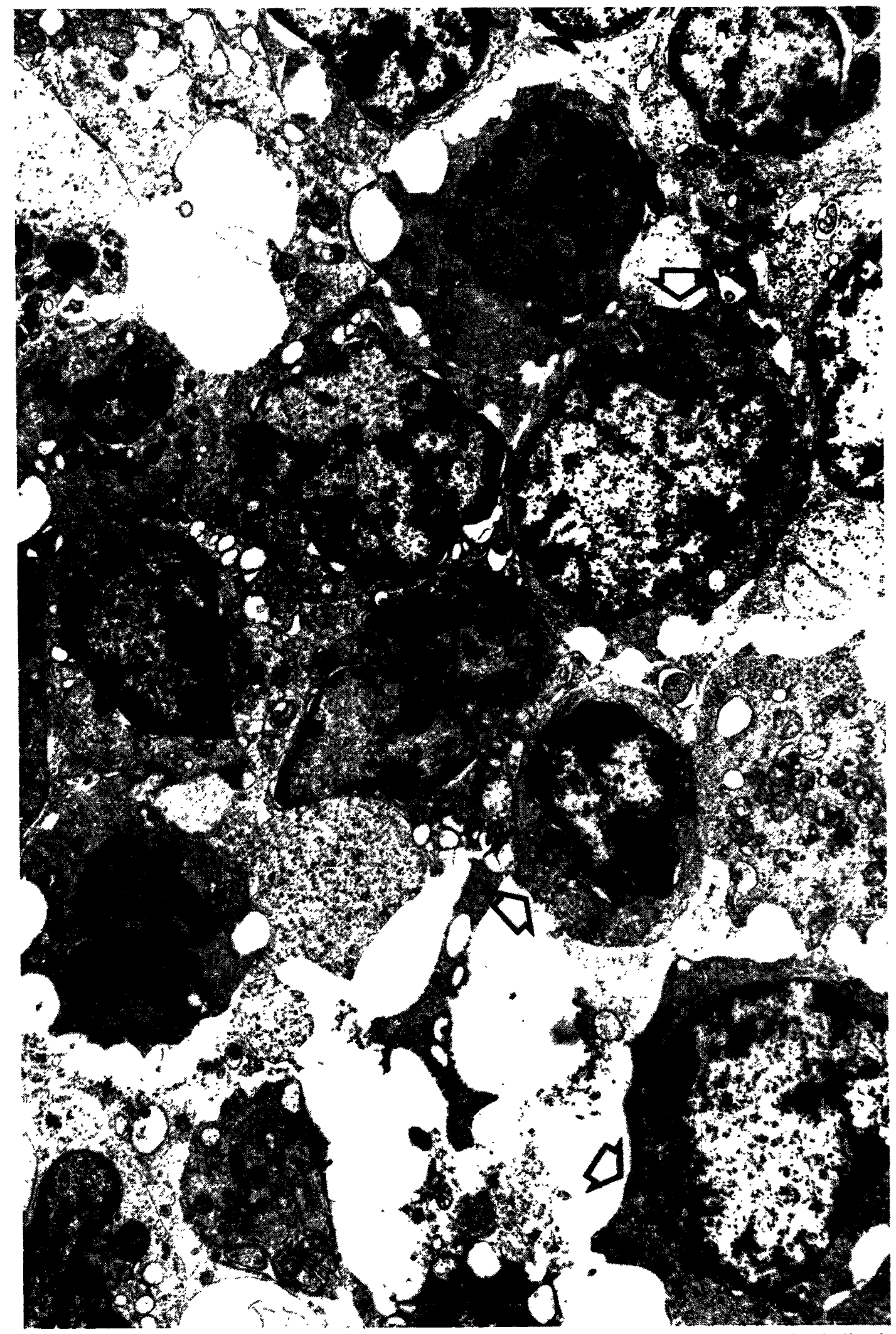

Fig. 3. Electron micrograph of neoplastic cells from case of calf form (Case No. 14), indicating variations in their size, nuclear membrane contours, and nuclear content. The cytoplasm is scant and cellular organella are poorly developed with only a small number of mitochondria and rER. A clustered dense body (arrows) of lysosomes measuring $0.1-0.6 \mathrm{~nm}$ corresponded to the recess of nuclear membrane. $\times 6,080$. 
were generally found more frequently among paracortical lymphocytes. Type I cells tended to be found in the perifollicular portions and medullary cords, whereas type III cells tended to be found among the macrophages in the medullary sinuses.

Enzyme activity in the lymph nodes of leukemic cattle: The superficial cervical lymph nodes in the leukemic cattle have lost their normal histological structure by diffuse proliferation of neoplastic cells.

ATPase. Most of the neoplastic cells produced a positive reaction in 10 of 12 adult form (Fig. 1). The findings in these positive cells were similar to those of B lymphocyte dependent areas of normal lymph nodes. In 6 cattle of thymic and calf forms, on the other hand, findings were different from those in adult form. A negative reaction was exhibited in these cells.

AcPase. Scattered type I and III cells were found in the neoplastic cells of the 12 adult form cattle. Most of the neoplastic cells, however, gave a negative reaction. Type III cells were frequently found in the large macrophages. In the 6 cattle of thymic and calf form, on the other hand, specific reactions were found. Many of the neoplastic cells showed type II reaction with positive granules dark brown in color localized at one side of the cytoplasm (Fig. 2). The morphological aspects of such cells with positive reaction closely resembled those of normal lymphocytes in the paracortex, $\mathrm{T}$ lymphocyte dependent area.

Electron microscopic observations: Neoplastic cells of adult form exhibited long and short surface microvilli. Recesses of nuclear pockets were present in the nuclei. Aggregations of nuclear chromatin and a large nucleoli were noted. The cytoplasm was generally narrow, containing abundant polysomes and a few mitochondria, rough endoplasmic reticulum (rER) and scattered lysosomes with diameter of $0.1-0.5 \mathrm{~nm}$. The surface of the cell membrane of thymic form neoplastic cell was mostly smooth. The round nucleus contained abundant heterochromatin in the karyoplasm, showing an occasional recess of nuclear membrane. The cytoplasm was scant and cellular organella were poorly developed with only a small number of mitochondria and rER. A clustered dense body (CDB) of lysosomes measuring $0.1-0.6 \mathrm{~nm}$ corresponded to the recess of nuclear membrane. In the calf form, surface of the cell membrane was relatively smooth, closely resembling the thymic form neoplastic cells. The heterogenecity of the nucleus was pronounced, frequently with complex indentations. In the cytoplasm of the nuclear recess, CDB consisting of a large number of lysosomes were noted (Fig. 3). In 2 calf form (Case Nos. 13 and $15)$, the numbers of $\mathrm{CDB}$ was $42 \%(132 / 300$ cells) and $62 \%$ (186/300 cells) respectively.

\section{DISCUSSION}

T and B lymphocytes have been characterized through elucidations of membrane characteristics by anti-thymic serum (ATS) and surface immunoglobulin (SIg) [9, 17, 21]. Morphologically, scanning electron microscopic observations revealed a relatively smooth surface on the $\mathrm{T}$ lymphocytes [19]. Abundant villi were present on the surface of B lymphocytes. From transmission electron microscopy, $\mathrm{T}$ cells are known to exhibit a CDB consisting of lysosomes localized within the cytoplasm [5, 8, 19]. Recently, ATPase and AcPase have received attention as a marker for $B$ and $T$ lymphocytes respectively in human studies. In the B lymphocyte dependent areas of the lymph nodes, many lymphocytes with intense ATPase activity on the cell membrane were noted [14]. Neoplastic cells of malignant lymphoma considered to be derived from $B$ lymphocytes demonstrated ATPase activity $[6,7,13]$. Few reports deal with the enzyme activity of bovine lymphocytes. B cell characteristics of adult form bovine leukosis have been demonstrated by immunological methods and scann- 
ing microscopy $[2,12,16,23]$. In the present study, many of the neoplastic cells of adult form showed ATPase activity as seen in the B lymphocyte dependent areas of the normal lymph nodes. This, suggests a B lymphocyte origin not only immunologically but also from the enzymatic standpoint. Membrane ATPase activity of lymphocytes is thought to participate in the secretion of immunoglobulin [1]. ATPase activity is required for energy transport in and out of the cells [11]. Presence or absence of ATPase activity might express the functional differentiation of B lymphocytes. Lymphocytes in the $T$ lymphocyte dependent area of the lymph node, on the other hand, showed AcPase activity. In human $T$ leukemia cell, localized positive AcPase activity has been demonstrated $[4,5]$. The large number of $T$ lymphocytes forming E-rosette showed AcPase activity $[14,20]$. In the present study, AcPase activity was demonstrated in the cells of T lymphocyte dependent area of the lymph nodes of healthy cattle. It indicated the possibility of application of this enzyme as a marker for T lymphocytes. Although AcPase activity was demonstrated in macrophages as well, it was clearly distinguishable from the positive findings in $\mathrm{T}$ lymphocytes. These macrophages appeared as type III cells. Most of the adult form neoplastic cells, on the other hand, gave a negative reaction. Many of the thymic and calf form neoplastic cells showed type II reaction suggesting $\mathrm{T}$ cell origin. The findings suggest a difference between thymic and calf form neoplastic cells and adult form ones histochemically. AcPase is also called a lysosomal enzyme [5, 8]. Its activity has been demonstrated along with intracytoplasmic lysosomes electron microscopically. Watanabe et al. [19] observed CDB in 76\% of $\mathrm{T}$ lymphocytes in the paracortex of the lymph node and suggested the usefulness of $\mathrm{CDB}$ as one of the morphological indices of $\mathrm{T}$ lymphocytes. In the present study, presence of $\mathrm{CDB}$ and AcPase activity showed almost the same tendency between the thymic and calf form neoplastic cells. This suggests a similar cytological origin of these two forms of leukemic cells. Establishment of the immunological property of these two forms of cells by the use of monoclonal antibody is now required.

The specificity of enzyme activity in bovine leukemic cells are reflect to that of normal lymphocytic subpopulation in lymph node. This fact is also thought to express cytological characteristics of each form of bovine leukosis. Enzyme histochemical studies thus appear to be effective method to elucidate the pathogenesis of bovine leukosis.

\section{REFERENCES}

1. Ågren, G., Nilsson, K., and Ronquist, G. 1976. $\mathrm{Mg}^{2+}$ and $\mathrm{Ca}^{2+}$ stimulated ATPase at the outer surface of human peripheral lymphocytes and hematopoietic cell lines. Correlation between enzyme activity and immunoglobulin. Acta Physiol. Scand. 98: 67-73.

2. Atluru, D., Johnson, D. W., Paul, P. S., Muscoplat, C. C. 1979. B-lymphocyte differentiation, using pokeweed mitogen stimulation: In vitro studies in leukemic and normal cattle. Am.J. Vet. Res. 40: 515-520.

3. Barka, T., and Anderson, P. J. 1962. Histochemical methods for acid phosphatase using hexazonium pararosanilin as coupler. J. Histochem. Cytochem. 10: 741-753.

4. Catovsky, D., Galetto, J., Okas, A., Miliani, E., and Galton, D. A. G. 1974. Cytochemical profile of $B$ and $T$ leukemic lymphocytes with special reference to acute lymphoblastic leukemia. $J$. Clin. Pathol. 27: 767-771.

5. Costello, C., Catovsky, D., O'Brien, M., Morilla, R., and Varadi, S. 1980. Chronic T-cell leukemias. I. Morphology, cytochemistry and ultrastructure. Leuk, Res. 4: 463-476.

6. Harigaya, K., Mitaka, A., Suzuki, H., Ohnishi, T., Kageyama, K., Minato, K., and Shimoyama, M. 1979 . $\mathrm{Mg}^{2+}$-dependent adenosine triphosphatase as an enzyme histochemical marker for the lymphomas of B-cell origin. Am. J. Pathol. 97: 359-380.

7. Harigaya, K., Mitaka, A., Suzuki, H., Ohnishi, T., and Watanabe, S. 1977. Enzyme cyto- and histochemical approach to lymphoreticular malignancies. Recent. Adv. RES Res. 17: 79-96.

8. Kataoka, K., and Minowada, J. 1979. Human T 
and B lymphoid cells: An electron microscopic study on thymocytes, peripheral blood lymphocytes, mitogen- stimulated cells and lymphoid cell lines. Arch. Histol. Jpn. 42: 355-374.

9. Kikuchi, K., Ishii, Y., Koshiba, H., Yamanaka, N., and Mikuni, C. 1976. Surface antigenic markers and receptors for human $\mathrm{T}$ and $\mathrm{B}$ cells and lymphoproliferative disorders. Tumor Res. 11: 19-26.

10. Koyama, H., Hohdatsu, T., Kajikawa, O., Tsubaki, s., Yoshikawa, H., Yoshikawa, T., and Saitoh, H. 1981. Optimal titer of bovine leukemia virus antigen for immunodiffusion test. J. Jpn. Vet. Med. Assoc. 34: 374-378 (in Japanese with English summary).

11. Kragbelle, K., and Ellegaad, J. 1978. ATPase activity of purified human normal $\mathrm{T}$ - and Blymphocytes. Scand. J. Haematol. 20: 271-279.

12. Kumar, S. P., Paul, P. S., Pomeroy, K. A., Johnson, D. W., Muscoplat, C. C., Van Der Maaten, M. J., and sorensen, D. K. 1978. Frequency of lymphocytes bearing $F c$ receptors and surface membrane immunoglobulins in normal, persistent lymphocytotic and leukemic cows. Am. J. Vet. Res. 39: 45-49.

13. Mikata, A., Harigaya, K., Watanabe, S., Ohnishi, T., and Suzuki, H. 1978. Morphological and enzyme histochemical approaches for the classification of non-Hodgkins lymphoma. Recent Adv. RES Res. 10: 105-118.

14. Müller-Hermelink, H. K. 1974. Characterization of B-cell and $\mathrm{T}$-cell regions of human lymphatic tissue through enzyme histochemical demonstration of ATPase and 5-Nucleotidase activities. Virchows Arch. [Cell Pathol.]. 16: 371-378.

15. Stein, H., Petersen, N., Gaedicke, G., Lennert, K., and Landbeck, G. 1976. Lymphoblastic lymphoma of convoluted or acid phosphatase type-
A. Tumor of T precursor cells. Int. J. Cancer 17 : 292-295.

16. Takashima, I., Olson, C., Driscoll, D. M., and Baumgartner, L. E. 1977. B-and T-lymphocytes in three types of bovine lymphosarcoma. J. Nat. Cancer Inst. 59: 1205-1209.

17. Van Heerde, P., Feltkamp, C. A., FeltkampVroom, T. M., Koudstaal, J., and Van Unnit, J. A. M. 1980. Non-Hodgkins lymphoma. Immunohistochemical and electron microscopical findings in relation to lightmicroscopy. A study of 74 cases. Cancer 46: 2210-2220.

18. Wachstein, M., and Meiseel, E. 1957. Histochemistry of hepatic phosphatase at a physiologic $\mathrm{pH}$. Am. J. Clin. Pathol. 27: 13-23.

19. Watanabe, Y., Tamaoki, N., Habu, S., Tashiro, Y., Akatsuka, S., and Enomoto, Y. 1974. Fine Structural study on human T-and B-lymphocytes. Acta Haem. Jap. 37: 655-666.

20. Wehinger, H., and Mobius, W. 1976. Cytochemical study on $\mathrm{T}$ and B lymphocytes and lymphoblasts with special reference to acid phosphatase. Acta Haematol. 56: 129-136.

21. Yamanaka, N., Ishii, Y., Koshiba, H., Mikuni, C., Kouno, M., and Kikuchi, K. 1978. A study of surface markers in ALL by using anti B lymphocyte sera. Cancer 42: 2641-2647.

22. Yang, K., Bearman, R. M., Pangalis, G. A., Zelman, R. J., and Rappaport, H. 1982. Acid phosphatase and alpha-naphthyl acetate esterase in neoplastic and non-neoplastic lymphocytes. A statistical analysis. Am. J. Clin. Pathol. 78: 141-149.

23. Yoshikawa, T., Oyamada, T., Yoshikawa, H., Koyama, H., and Komoriya, Y., 1983. Scanning electron microscopic study of bovine leukemic cells. Am. J. Vet. Res. 44: 1356-1362.

要 約

牛白血病細胞の酵素組織化学的研究：吉川 堯・山村高章・吉川博康 - 小山田敏文(北里大学獣医病理学教室) 一一牛白血病18例（成牛型12例, 胸腺型 3 例, 子牛型 3 例）の腫湟化浅頸リンパ節および健康牛 5 例の浅頚リン パ節細胞について ATPase およびAcPase の酵素化学的活性を検討した。健康牛のリンパ節において，ATPase

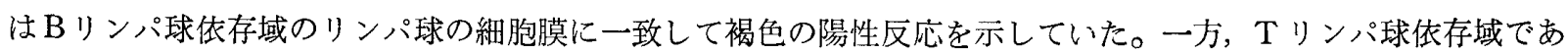
る副皮質のリンパ球細胞質内には AcPase 活性を示す黒褐色の顆粒が集合して認められた。成牛型白血病12例中 10例の腫瘍細胞は明らかにATPase 活性を示していたが，胸腺および子牛型 6 例の腫瘍細胞は殆んど陰性を示し ていた。しかしこれら6例の腫湯細胞はいずれも AcPase 陽性の集合性顆粒を含んでいた。なお AcPase陽性 の集合性顆粒は電顕的に clustered dense body として観察された。牛白血病の腫瘍細胞は正常リンパ節リンパ球 の酵素活性を比較的忠実に反映しているとみなされた。酵素組織化学的検索は牛白血病の各型の病態解析に有力 な一方法であると考える。 